\title{
Different responses to infectious hypodermal and hematopoietic necrosis virus (IHHNV) in Penaeus monodon and P. vannamei
}

\author{
Kanokporn Chayaburakul ${ }^{1}$, Donald V. Lightner ${ }^{3}$, Siriporn Sriurairattana ${ }^{2}$, \\ Kathy Tang Nelson ${ }^{3}$, Boonsirm Withyachumnarnkul ${ }^{1,2, *}$ \\ ${ }^{1}$ Department of Anatomy, and ${ }^{2}$ Centex Shrimp, Faculty of Science, Mahidol University, Rama 6 Rd., Bangkok 10400, Thailand \\ ${ }^{3}$ Department of Veterinary Science and Microbiology, University of Arizona, Tucson, Arizona 85721-0090, USA
}

\begin{abstract}
Infectious hypodermal and hematopoietic necrosis virus (IHHNV) is widespread in cultured Penaeus monodon and P. vannamei in Thailand. It causes runt-deformity syndrome that is characterized by physical abnormalities and stunted growth in $P$. vannamei, but causes no apparent disease in $P$. monodon. In both species, the virus may produce Cowdry Type A inclusions in tissues of ectodermal and mesodermal origin, but these are common in $P$. vannamei and rare in $P$. monodon. The virus can be more easily detected in both species by IHHNV-specific PCR primers. By in situ hybridization (ISH) using specific IHHNV probes, fixed phagocytes associated with myocardial cells tended to show strong positive reactions in both shrimp species. Ovarian and neural tissue (neurons in the nerve ganglia and glial cells in the nerve cord) were ISH positive for IHHNV only in $P$. vannamei. By transmission electron microscopy, necrotic cells were found in the gills of IHHNV-infected $P$. vannamei, while paracrystalline arrays of virions and apoptotic cells rather than necrotic cells were found in the lymphoid organ of IHHNV-infected $P$. monodon. Thus, it is possible that apoptosis in $P$. monodon contributes to the absence of clinical disease from IHHNV. These findings reveal different responses to IHHNV infection by the 2 shrimp species. A curious feature of IHHNV infection in $P$. monodon was inconsistency in the comparative viral load amongst tissues of different specimens, as detected by both ISH and real-time PCR. This inconsistency in apparent tissue preference and the reasons for different cellular responses between the 2 shrimp species remain unexplained.
\end{abstract}

KEY WORDS: Infectious hypodermal and hematopoietic necrosis virus · IHHNV · Penaeus monodon • Penaeus vannamei · Differential response

Resale or republication not permitted without written consent of the publishe

\section{INTRODUCTION}

Infectious hypodermal and hematopoietic necrosis virus (IHHNV) is a small DNA virus in the family Parvoviridae (Shike et al. 2000) that infects several panaeid shrimp. Its size, DNA sequence and structural proteins have been reasonably well documented (Bonami et al. 1990, Mari et al. 1993, Regenmortel et al. 2000). The genome of IHHNV from infected Penaeus monodon in Thailand shares $96.2 \%$ identity with IHHNV from infected $P$. vannamei from Hawaii (Tang et al. 2003). Infection by IHHNV in penaeid shrimp was first reported in P. stylirostris in Hawaii in 1981, when an outbreak caused $90 \%$ mass mortality in juvenile shrimp (Lightner et al. 1983a,b). It apparently originated from grossly healthy experimental stocks of $P$. monodon imported from Asia (Lightner 1996a). In $P$. vannamei, the virus usually causes runt-deformity syndrome (RDS) (Kalagayan et al. 1991), which is typically a chronic, non-lethal disease (Lightner et al. 1983b). Infection by IHHNV in $P$. monodon has largely been ignored, although it has been reported in juvenile shrimp of this species (Lightner et al. 1983b, Flegel et al. 1992) and as the apparent cause of RDS in some 
stocks of IHHNV-infected $P$. monodon in the Philippines (Primavera \& Quinitio 2000). A recent finding of high prevalence of IHHNV in wild and domesticated P. monodon broodstock in Southeast Asia (Flegel et al. 2004) suggests that more attention should be given to its potential effects.

Cells that are infected by IHHNV usually display central, eosinophilic inclusions in enlarged nuclei that contain marginated chromatin. These inclusions, termed Cowdry Type A inclusions (CAI), are variably positive for DNA with Feulgen stain. The trophic tissues for IHHNV infection are of ectodermal and mesodermal origin. Ectodermal targets include gills, cuticular epidermis, hypodermal epithelium of the foregut and hindgut, nerve cords and nerve ganglia, while mesodermal targets include hematopoietic tissue, antennal glands, gonads, lymphoid organs, connective tissue and striated muscle (Bell \& Lightner 1984, Lightner 1996b). In the mysis or early postlarval stages, CAI suggestive of IHHNV infection have been reported to occur in the midgut epithelium as well (Lightner 1996b).

The purpose of this study was to investigate the cellular responses of Penaeus monodon to IHHNV infection and to compare this with the cellular responses in $P$. vannamei.

\section{MATERIALS AND METHODS}

Animals. Seventeen Penaeus monodon (20 to $25 \mathrm{~g}$ ) and 13 P. vannamei (8 to $10 \mathrm{~g}$ ) juveniles, 4 mo in culture, that were positive for IHHNV by polymerase chain reaction (PCR) were obtained from commercial shrimp farms in Thailand. All of the $P$. vannamei shrimp showed typical RDS (Lightner et al. 1983b), whereas all of the P. monodon shrimp showed no morphological abnormalities in their external features, as well as no growth retardation. Ten of each species were processed for routine light microscopic (LM) paraffin sectioning with hematoxylin/eosin (H\&E) staining and in situ hybridization; $4 P$. monodon, for real-time $\mathrm{PCR}_{i}$ and 3 of each species for transmission electron microscopy (TEM).

Histopathology. The dissection and fixation procedures were based on those of Bell \& Lightner (1988). A transverse cut was made between the posterior end of the cephalothorax and the first abdominal segment, the abdomen was discarded and only the cephalothorax was fixed. After fixation, samples were transferred to $70 \%$ ethanol until processing for histology using standard methods with routine H\&E staining. Tissue sections from these samples were also used for in situ hybridization (ISH) with a IHHNV-specific probe. Both H\&E and ISH sections were viewed under LM.
ISH. Paraffin sections ( $4 \mu \mathrm{m}$ thick) were placed on positively charged microscope slides (HistoBond), deparafinized by heating for 30 to $45 \mathrm{~min}$ at $65^{\circ} \mathrm{C}$, rehydrated and then reacted with a DIG-labeled probe (IHHNV-In Situ ShrimProbe, DiagXotics) following the protocol recommended by the manufacturer. The resulting slides were examined using LM for cells displaying a dark-blue to dark-purple precipitate, indicating the presence of hybridized IHHNV DNA.

TEM. Individual organs (lymphoid organs, gills, neural tissues, hearts, muscles, hematopoietic tissue, antennal gland tissue, subcuticular epidermis and hepatopancreatic tissue) were fixed in $6 \%$ glutaraldehyde (0.15 Millonig's phosphate buffer, $\mathrm{pH} 7.0$, supplemented with $1 \%$ sodium chloride and $0.5 \%$ sucrose) (Lightner 1996b). Ice-cold fixative, approximately 1/10 of the total volume of the shrimp, was first injected into the hepatopancreas. Then, the shrimp infused with the fixative were placed in a shallow container with the ice-cold $\left(\sim 4^{\circ} \mathrm{C}\right)$ phosphate buffer for tissue or organ dissection. Small pieces $\left(\sim 1 \mathrm{~mm}^{3}\right)$ of tissue were transferred to $1 \mathrm{ml}$ of the same fixative for an additional $6 \mathrm{~h}$ at $4^{\circ} \mathrm{C}$. Tissue was then processed for TEM observation, using Araldite as embedding medium (Chayaburakul et al. 2004).

PCR for IHHNV detection. Shrimp samples infected with IHHNV were identified by PCR using a commercial kit (Intelligene IQ 2000). To confirm infections, a second PCR test was run using primers (1533F and 1712R) developed with the program Primer 4 (Scientific \& Educational Software) applied to IHHNV GenBank Sequence AF218266 and resulting in amplification of a fragment of $180 \mathrm{bp}$ between Positions 1533 and 1712 .

Pleopods (20 to $25 \mathrm{mg}$ ) from shrimp samples were stored in $95 \%$ ethanol, and DNA extraction was carried out using a commercial kit (Qiagen). The PCR reaction volume of $50 \mu \mathrm{l}$ buffer $(10 \mathrm{mM}$ Tris- $\mathrm{HCl}$, $50 \mathrm{mM} \mathrm{KCl}, \mathrm{pH} 8.3$ ) contained the primers $1533 \mathrm{~F}$ and 1712R (1 $\mu \mathrm{M}$ each), dNTPs (10 mM each), Taq polymerase (Qiagen) (2.5 U per $50 \mu \mathrm{l}), \mathrm{MgCl}_{2}(15 \mathrm{mM})$ and $5 \mu \mathrm{l}$ template solution. The PCR protocol comprised predenaturation at $95^{\circ} \mathrm{C}$ for $5 \mathrm{~min}$, followed by 35 cycles of denaturation at $94^{\circ} \mathrm{C}$ for $30 \mathrm{~s}$, annealing at $52^{\circ} \mathrm{C}$ for $30 \mathrm{~s}$ and polymerization at $72^{\circ} \mathrm{C}$ for $30 \mathrm{~s}$. Following the last cycle, the samples were polymerized for $7 \mathrm{~min}$ at $72^{\circ} \mathrm{C}$ and then held at $4^{\circ} \mathrm{C}$ until analyzed by $1.5 \%$ agarose gel electrophoresis. DNA patterns in the agarose gels were visualized by UV light and photographed with Gel Documentation (Syngene). To verify specificity, the primers $1533 \mathrm{~F}$ and 1712R were tested with templates containing genomic extracts of white-spot syndrome virus (WSSV), monodon baculovirus (MBV) and hepatopancreatic parvovirus (HPV). 
Real-time PCR. Quantitative real-time PCR was carried out using Penaeus monodon only. Two IHHNVinfected P. monodon (4 mo of culture) were offspring of wild broodstock and another 2 were from domesticated stock. Tissues (heart, gill, hematopoietic tissue, subcutaneous tissue, hepatopancreas, pleopods, abdominal muscle, ventral nerve cord and lymphoid organ) were aseptically removed, and DNA was extracted to make duplicate templates for real-time PCR assays using the standards and protocol described by Tang \& Lightner (2001). A sample of $10 \mathrm{ng}$ of DNA was added to the PCR mixture containing $0.3 \mu \mathrm{m}$ of each primer and $0.15 \mu \mathrm{m}$ of TaqMan probe, in a volume of $25 \mu \mathrm{m}$. Amplification was performed with the GeneAmp 5700 (PE Applied Biosystems) model, with fluorescence measurements taken by a built-in charge couple device (CCD) camera. Each sample was tested in duplicate, and the result was considered positive only if both replicates were positive. To confirm the TaqMan assay results, an aliquot of PCR product was subjected to electrophoresis on a $4 \%$ EtBr-agarose gel and photographed.

\section{RESULTS}

\section{Histology}

By LM, no CAI were found in any histological sections of the IHHNV PCR positive (+ve) Penaeus monodon. By contrast, sections of $P$. vannamei IHHNV PCR +ve specimens showed typical CAI, especially in the antennal gland and nerve cord; the severity of infection, as judged from Bell's severity grading (Bell \& Lightner 1987), was at the level of $2 / 4$.

\section{ISH}

ISH for IHHNV were found in cells from both shrimp species; for Penaeus vannamei, all 10 animals showed obvious positive reactions; however, only 2 out of $10 \mathrm{P}$. monodon showed positive reactions. The tissues that showed positive signals included hemocytes, connective tissue cells in the hemal spaces between hepatopancreatic tubules (Fig. 1a,b), skeletal muscle (Fig. 1c), hematopoietic tissue (Fig. 1d) and antennal gland tubules (Fig. 1e). Other positive cell types were pillar cells in the gill lamallae (Fig. 1f) and fixed phagocytes associated with myocardial cells in the heart (Fig. 2c,d). Tissues that were ISH +ve in $P$. vannamei, but negative in $P$. monodon, included nerve tissue (the epineurium, neurons and neuropile in the nerve cord and ganglia) (Fig. 3c,b) and the ovary (Fig. 3d). Hepatopancreatic tubule epithelial cells did not show any positive reactions. In P. monodon hematopoietic tissue, hematopoietic cells, but not connective tissue cells, were reactive (Fig. 1d). A strong ISH reaction was often observed in the heart, but this was associated mostly with fixed phagocytes and circulating hemocytes and not with cardiac muscle cells (Fig. 2c,d). Similar ISH reactions were observed in IHHNV PCR +ve $P$. vannamei (not shown). In P. vannamei, ISH positive cells included hemocytes in the hemal sinuses of the hepatopancreas, in skeletal muscle, in hematopoietic tissue and in the heart. Among all the tissues in both species examined by ISH, fixed phagocytes in the heart tended to show the most intensely positive ISH reaction, followed by the epithelial pillar cells of the gills.

However, IHHNV tissue distribution based on intensity of the ISH reaction for both Penaeus monodon and $P$. vannamei was inconsistent or variable in intensity amongst tissues from specimen to specimen. In other words, one organ or tissue would be most intense in one specimen and a different organ or tissue the most intense in another specimen. This feature correlated with the quantitative real-time PCR results for various tissues.

\section{Real-time PCR}

Mean copy numbers of the viral loads in various tissues of 4 IHHNV-infected Penaeus monodon samples are shown in Table 1 . There were no statistically significant differences because of the wide variation in overall infection level for the various specimens and for each tissue.

Table 1. Mean copy number (copies per $10 \mathrm{ng}$ DNA) in each organ extract from 4 IHHNV-infected Penaeus monodon. Shrimps 1 and 2 were farmed (offspring of wild broodstock), while Shrimps 3 and 4 were from domesticated stocks. Each value is the average of duplicate tests

\begin{tabular}{|lrrrr|}
\hline Tissue & \multicolumn{4}{c}{ Shrimp number } \\
& \multicolumn{1}{c}{1} & \multicolumn{1}{c|}{3} & \multicolumn{1}{c|}{4} \\
\hline Heart & $1.8 \times 10^{8}$ & $6.9 \times 10^{7}$ & $1.3 \times 10^{5}$ & $1.78 \times 10^{5}$ \\
Hematopoietic tissue & $1.5 \times 10^{8}$ & $4.26 \times 10^{6}$ & $1.2 \times 10^{5}$ & $1.36 \times 10^{5}$ \\
Gill & $9.1 \times 10^{6}$ & $8.5 \times 10^{6}$ & $1.5 \times 10^{5}$ & $7.3 \times 10^{5}$ \\
Subcutaneous tissue & $5.5 \times 10^{7}$ & $7.3 \times 10^{6}$ & $6.1 \times 10^{3}$ & $2.56 \times 10^{6}$ \\
Hepatopancreas & $2.8 \times 10^{5}$ & $2.3 \times 10^{7}$ & $3.6 \times 10^{6}$ & $9.97 \times 10^{3}$ \\
Pleopod & $4.4 \times 10^{7}$ & $1.3 \times 10^{7}$ & $2.1 \times 10^{3}$ & $2.41 \times 10^{5}$ \\
Abdominal muscle & $6.15 \times 10^{6}$ & $4.3 \times 10^{2}$ & $2.3 \times 10^{3}$ & $5.7 \times 10^{4}$ \\
Ventral nerve cord & $7.5 \times 10^{5}$ & $5.2 \times 10^{2}$ & $1.1 \times 10^{4}$ & $1.28 \times 10^{5}$ \\
Lymphoid organ & & $5.1 \times 10^{6}$ & $2.36 \times 10^{4}$ & $2.8 \times 10^{5}$ \\
Hemolymph & & & $4.14 \times 10^{4}$ & $4.6 \times 10^{6}$ \\
\hline
\end{tabular}



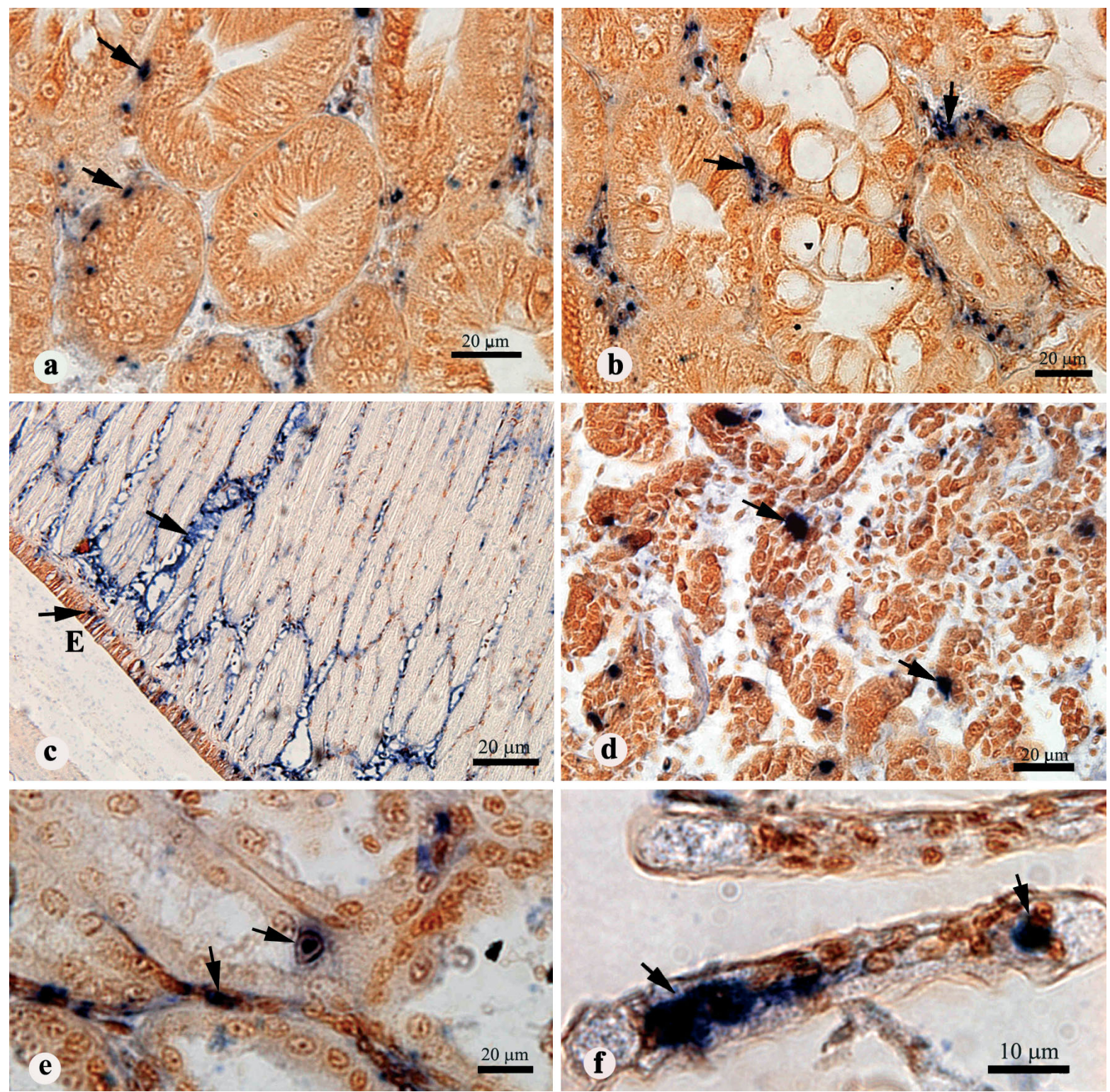

Fig. 1. Penaeus monodon. Photomicrographs of tissues from juveniles that were PCR positive for infectious hypodermal and hematopoietic necrosis virus (IHHNV) and processed through in situ hybridization (ISH) with specific DNA probes for IHHNV. ISH positive (+ve) cells for IHHNV stain blue-black; examples are shown in (a) to (f) (arrows). (a) A positive reaction is demonstrated in hemocytes in the hemal spaces among the apical or distal tips of the hepatopancreatic (HP) tubules; (b) more-proximal section through HP tubules showing IHHNV +ve hemocytes and connective tissue cells in the hemal spaces; (c) cuticular epithelium and striated muscle showing IHHNV +ve epithelial cells (E), hemocytes and connective tissue cells associated with muscle fibers that are non-reactive to the probe; (d) section through a hematopoietic nodule that shows a diffuse distribution of IHHNV +ve cells; (e) section through the antennal gland in which IHHNV +ve antennal gland tubule epithelial cells are shown, as well as IHHNV +ve hemocytes and connective tissues in the hemal sinus between antennal tubules; (f) section of the gills showing IHHNV +ve cells in the gill lamellae

To overcome the problem of wide variation and to facilitate comparison between shrimp specimens, the data were normalized. The copy number for each tissue of each shrimp was divided by the highest copy number and multiplied by 100 . This gave an infection index of 100 for the heaviest viral load in each shrimp and propor- tionally lower indexes for other tissues (Table 2). Again, differences in the median index values among tissues in 4 shrimp samples were not significantly different (ANOVA, $p=0.121$ ). On the other hand, the power of the statistical tests was low, and analysis of a larger number of specimens may change this interpretation. 
Table 2. IHHNV infection index for various tissues in individual Penaeus monodon

\begin{tabular}{|lrrrr|}
\hline \multirow{2}{*}{ Tissue } & \multicolumn{4}{c}{ Shrimp number } \\
& \multicolumn{1}{c}{1} & \multicolumn{1}{c|}{2} & \multicolumn{1}{c|}{3} \\
\hline Heart & 100.00 & 100.00 & 3.61 & 3.87 \\
Hematopoietic tissue & 83.33 & 6.17 & 3.33 & 2.96 \\
Gill & 5.06 & 12.32 & 4.17 & 15.87 \\
Subcutaneous tissue & 30.56 & 10.58 & 0.17 & 55.65 \\
Hepatopancreas & 0.16 & 33.33 & 100.00 & 0.22 \\
Pleopod & 24.44 & 18.84 & 0.06 & 5.24 \\
Abdominal muscle & 0.03 & 0.00 & 0.06 & 1.24 \\
Ventral nerve cord & 0.42 & 0.00 & 0.31 & 2.78 \\
Lymphoid organ & & 7.39 & 0.66 & 6.09 \\
Hemolymph & & & 1.15 & 100.00 \\
\hline
\end{tabular}

\section{TEM}

The lymphoid organ of the 3 IHHNV PCR +ve Penaeus monodon contained cells with paracrystalline arrays of viral particles (Fig. 4a,b) and apoptotic cells (Fig. 4c-e). By contrast, cellular necrosis was observed in all $3 P$. vannamei. Viral particles (presumed to be IHHNV) were found both in nuclei (Fig. 5c,d) and in the cytoplasm (Fig. 5a,b) of an IHHNV-infected cell in $P$. vannamei. These presumed IHHN viral particles were $22 \mathrm{~nm}$ in diameter and were also found in the cytoplasm of lymphoid organ cells in $P$. monodon (Fig. 4f). Intranuclear inclusions were found in antennal gland epithelial cells of $P$. vannamei (Fig. 5e,f), but not in $P$. monodon, in which the gland contained apoptotic cells. Late stages of apoptosis were apparent as affected cells showed degenerated nuclei (Fig. 4c) and nuclear fragments (apoptotic bodies) (Fig. 4d,e). In $P$. vannamei, no apoptotic cells were observed, but necrotic cells were found in the gills. The nuclear membrane was detached, and the cytoplasm was invaginated and digitated into the detached nuclear membrane space (Fig. 6b-d). Tubules of the rough endoplasmic reticulum (RER) were swollen (Fig. 6a). These necrotic cells in the gills with separated layers of the nuclear membrane were not observed in $P$. monodon.
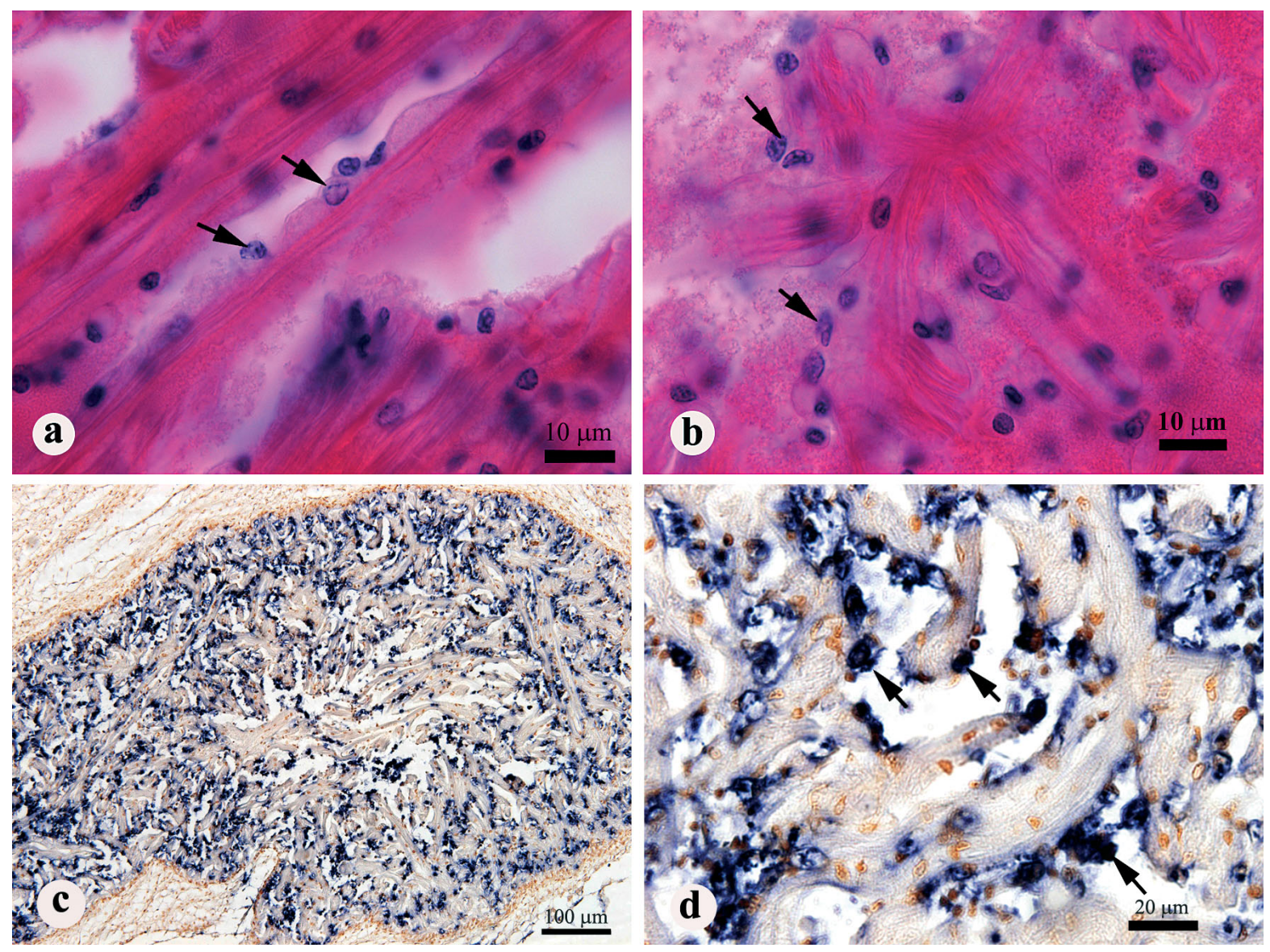

Fig. 2. Penaeus monodon. Histological sections from an IHHNV-infected specimen. (a,b) Hematoxylin/eosin (H\&E)-stained sections showing the presence of fixed phagocytes on myocardial fibers (arrows). (c,d) ISH sections showing an intense IHHNV +ve reaction with hemocytes and fixed phagocytes, but not with myocardial cells 

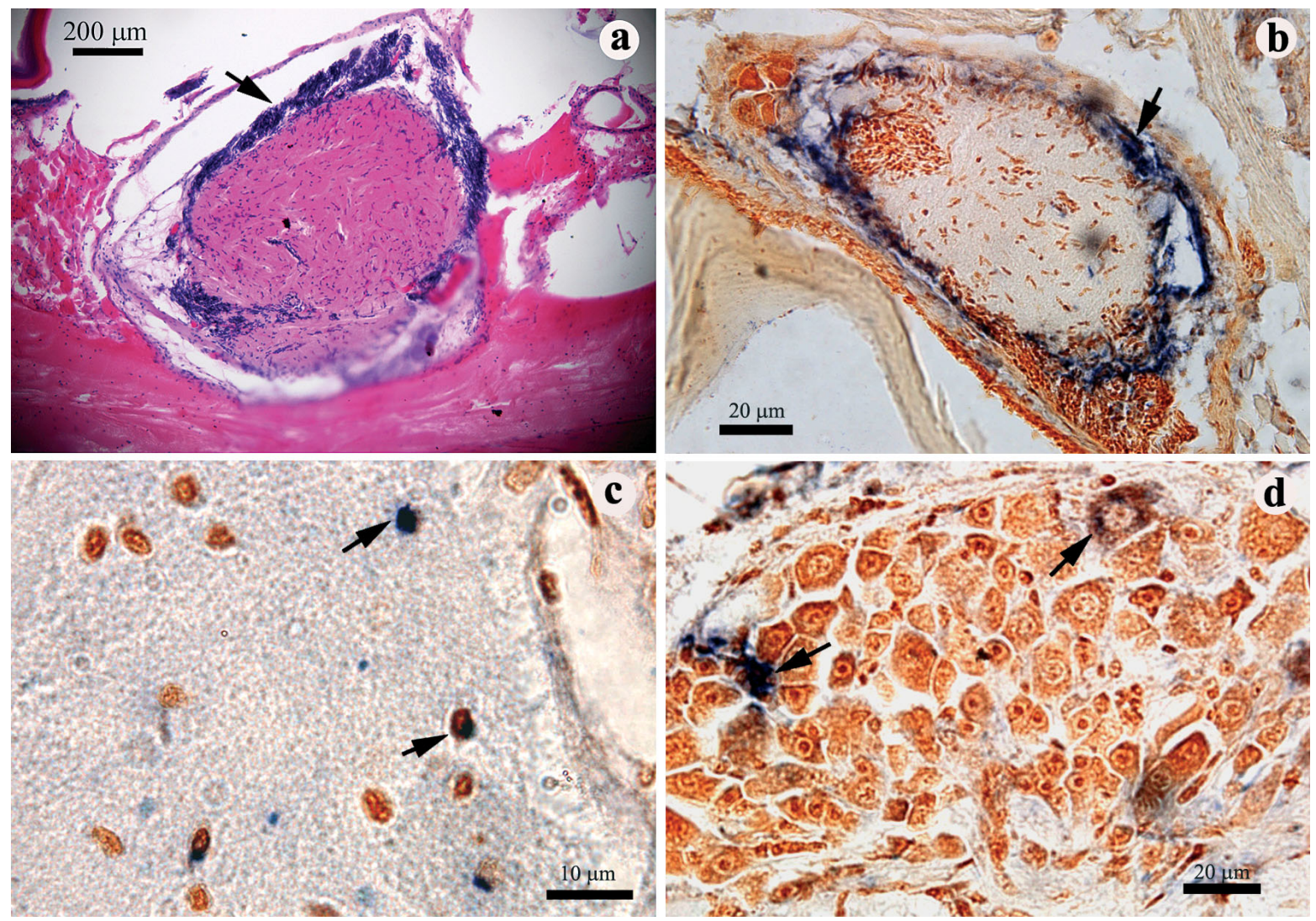

Fig. 3. Penaeus vannamei. Examples of positive ISH reactions for IHHNV found in neural tissue. (a,b) Sections of a nerve ganglion stained with H\&E (a) and reacted with a probe to IHHNV (b). A strong IHHNV +ve reaction is shown in the epineurium that surrounds the ganglion. (c,d) At higher magnification, IHHNV +ve cells (arrows) are demonstrated in the neuropile (c) and in cells (arrows) associated with neurons (d) of the ganglion

\section{DISCUSSION}

\section{Histology and ISH}

Histopathology results showed that CAI were much more rarely seen in Penaeus monodon than in $P$. vannamei and may relate to the fact that IHHNV infection in $P$. monodon is generally less serious than in $P$. vannamei. The findings that most of the IHHNV PCR +ve $P$. monodon had no positive reaction by ISH, whereas all of the IHHNV PCR +ve P. vannamei did have, also suggest different levels of susceptibility to IHHNV between the 2 species. In addition, there was a curious inconsistency in the ISH reaction for IHHNV displayed in various tissues of both $P$. monodon and $P$. vannamei. This phenomenon has not been previously reported and is difficult to explain. One would expect a specific set of target organs and tissues for each viral pathogen and that the intensity of the ISH reaction would give some indication of this. It is possible that the variable intensity amongst tissues for various specimens depended on which organ was the first infected and that the ISH intensity of the others reflected the order of subsequent infection. Further work is needed to explain this phenomenon.

Despite the lack of a hierarchy in IHHNV tissue preference in individual shrimp specimens, ISH tests clearly showed that neural tissues of Penaeus vannamei, but not those of $P$. monodon, were infected with detectable levels of IHHNV. Perhaps this partially explains why $P$. vannamei suffers reduced growth rates and deformities in the cuticle (RDS syndrome) as a result of IHHNV infection, while $P$. monodon does not. RDS has been reported for IHHNV PCR +ve domesticated P. monodon from the Philippines (Primavera \& Quinitio 2000), but we did not observe it with IHHNV PCR +ve P. monodon in Thailand. Two recent surveys in Thailand revealed that farmed $P$. monodon experiencing slow growth and size variation were infected by several pathogens, including MBV, HPV, IHHNV, bacteria and protozoa, and that many shrimp had multiple infections (Chayaburakul et al. 2004, Flegel et al. 2004). In both studies, there was no statistical correlation between IHHNV infection and shrimp size. 

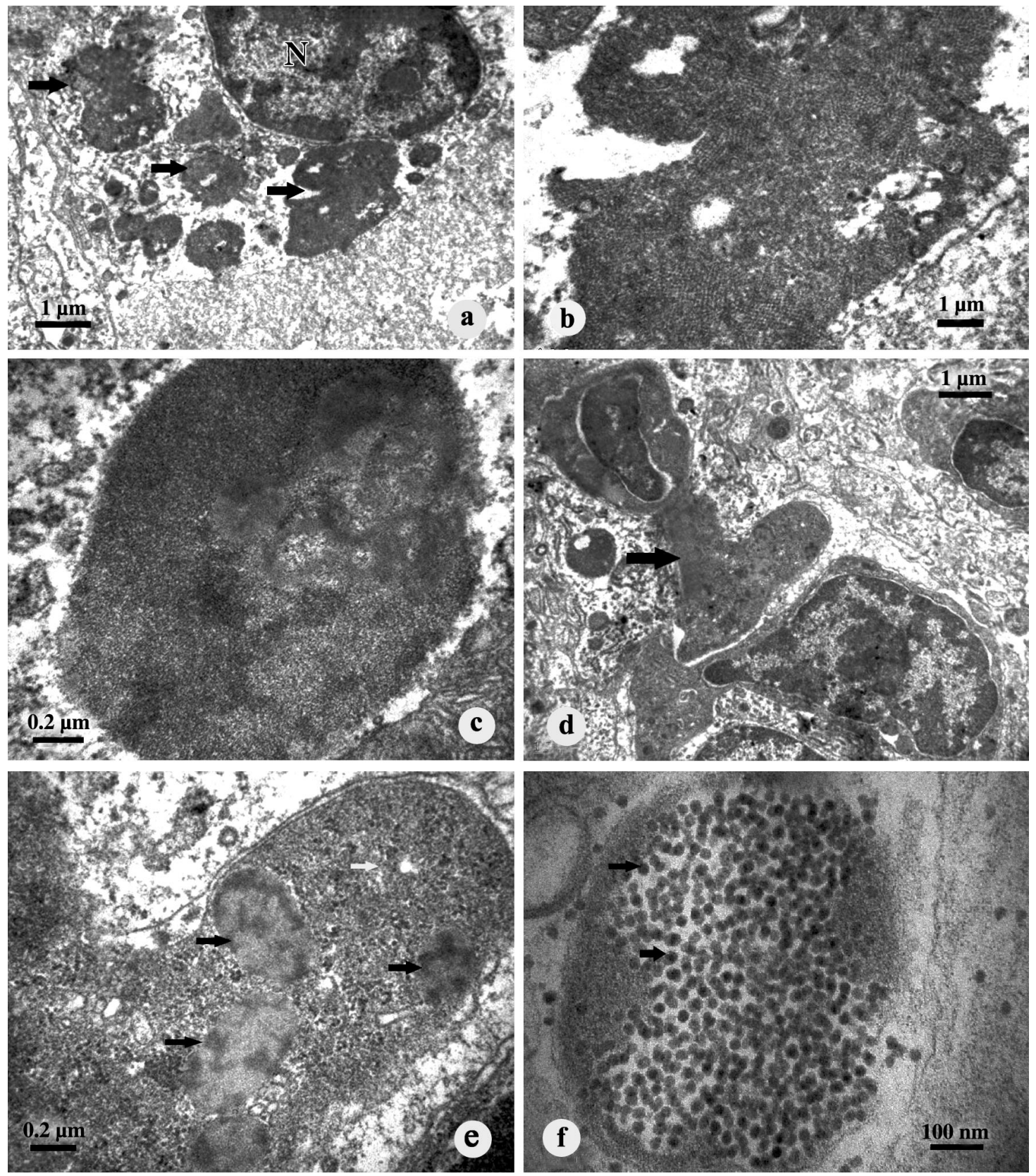

Fig. 4. Penaeus monodon. Transmission electron micrograph (TEM) of the lymphoid organ (LO) from IHHNV-infected specimens. Paracrystalline array of presumed IHHNV particles in a membrane-bound inclusion body in the cytoplasm of an LO cell shown at low (a, arrows) and high (b) magnification. An apoptotic cell in the LO is shown in which the cell nucleus has degenerated (c), and in which the nucleus has fragmented into many fragments called 'apoptotic bodies' (d,e: arrows). At high magnification, presumed IHHN viral particles $(22 \mathrm{~nm}$ ) in a cytoplasmic inclusion of an LO cell are shown (f, arrows)

\section{TEM}

Ultrastructural features of apoptosis have been described (Kerr et al. 1994, Hengartner 2000, Reed 2000), but, without supportive biochemical evidence, these alone should only be considered suggestive evidence of apoptosis. Based on the TEM results, it is possible that in Penaeus monodon, apoptosis limits the effects of
IHHNV infection. Cell death by apoptosis involves physiological and pathological processes during which individual cells undergo an internally controlled transition from normal metabolism to inactivity with a residue of shrunken cellular remnants that retain their membrane-bound integrity. A hallmark feature at the early stage is nuclear fragmentation without cytoplasmic changes. This is followed by cytoplasmic changes 

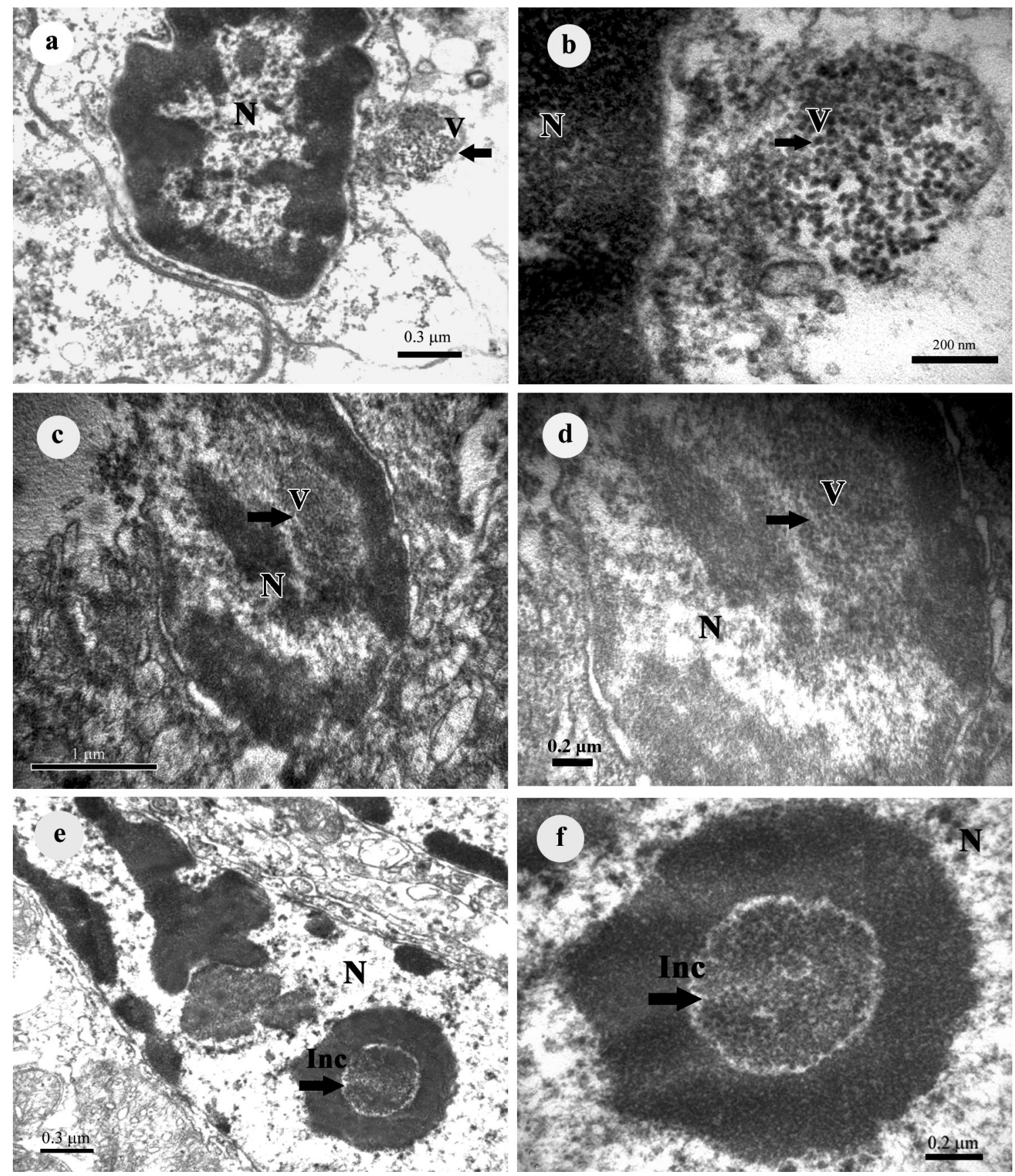

Fig. 5. Penaeus vannamei. TEM of gills (a to d) and the antennal gland (e,f) from IHHNV-infected specimens that differ from Penaeus monodon in which no signs of IHHNV infection were found by TEM. Presumed IHHN viral particles in a cytoplasmic vesicle associated with the nuclear membrane shown at low (a, arrow, V) and high (b, arrow, V) magnification. Intranuclear masses of presumed IHHN viral particles shown at low (c, arrow, V) and high magnification (d, arrow, V). Presumed IHHN viral particles in an antennal gland epithelial cell nucleus appeared as an inclusion shown at low (e, arrow, Inc) and high (f, arrow, Inc) magnification (N, nucleus)

and the formation of apoptotic bodies that are later engulfed by phagocytic cells. Since apoptosis was seen in IHHNV-infected $P$. monodon, but not in IHHNVinfected $P$. vannamei, it may be that the former can use apoptosis to control replication of IHHNV, while the latter cannot. Although ISH-positive tissues of both species were similarly infected, TEM showed cellular necrosis mainly in $P$. vannamei. Since both species can be infected by IHHNV, it is likely that both have appropriate viral receptors. Hence, it may be that their postreception mechanisms are different and that apoptosis is triggered in $P$. monodon, but not in $P$. vannamei. 

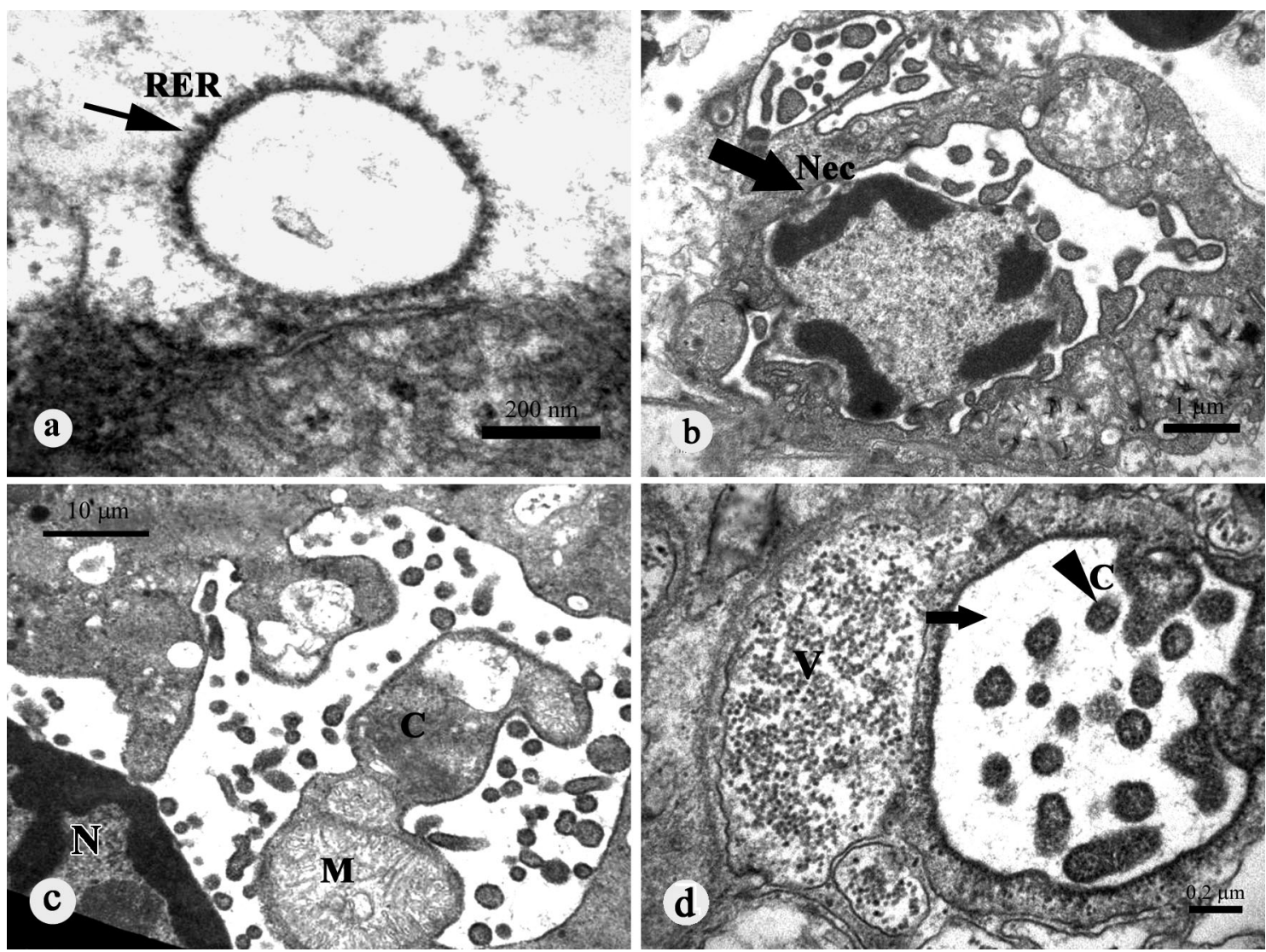

Fig. 6. Penaeus vannamei. TEM demonstrating cytopathologic changes in sections through the gills of an IHHNV-infected specimen. An apparently normal mitochondrion ( $\mathrm{a}$, bottom) adjacent to a swollen tubule of the rough endoplasmic reticulum (a, arrow, RER) was shown in one of the pillar cells. Necrotic pillar cells (b, arrow, Nec) with pycnotic nuclei $(c, N)$, a markedly enlarged space (b to d, arrow) between the layers of the nuclear membrane into which cytoplasmic projections (c, C \& d, C, arrowhead) have invaginated were shown. Shown in the cytoplasm of one of the affected cells is a membrane-bound mass of presumed IHHN viral particles (d, V)

Acknowledgements. This research was supported by PHD/ 0086/2543 from Golden Jubilee, Thailand Research Fund, and by Mahidol University Fund. We thank Kung Sam Farm, Chantabuli, Thailand, and Charoen Pokphand Foods Public Company, Sumut Sakhon, Thailand, for providing samples and Dr. Gary Nash from the Center of Genetic Engineering and Biotechnology, Thailand, for assistance in histology examinations. Special thanks also go to Bonnie T. Poulos and Carlos R. Pantoja, Department of Veterinary Science and Microbiology, University of Arizona, Tucson, AZ 85721, USA, for suggestions on IHHNV PCR and in situ hybridization. Lastly, we thank members of Centex Shrimp, Faculty of Science, Mahidol University, for giving advice on laboratory techniques.

\section{LITERATURE CITED}

Bell TA, Lightner DV (1984) IHHN virus: infectivity and pathogenicity studies in Penaeus stylirostris and Penaeus vannamei. Aquaculture 38:185-194

Bell TA, Lightner DV (1987) IHHN disease of Penaeus stylirostris: effects of shrimp size on disease expression. J Fish Dis 10:165-170

Bell TA, Lightner DV (1988) A handbook of normal shrimp histology. World Aquaculture Society, Baton Rouge, LA and Allen Press, Lawrence, KS

Bonami JR, Trumper B, Mari J, Brehelin M, Lightner DV (1990) Purification and characterization of the infectious hypodermal and haematopoietic necrosis virus of penaeid shrimps. J Gen Virol 71:2657-2664

Chayaburakul K, Nash G, Pratanpipat P, Sriurairatana S, Withyachumnarnkul B (2004) Multiple pathogens found in growth-retarded black tiger shrimp Penaeus monodon cultivated in Thailand. Dis Aquat Org 60:89-96

Flegel TW, Fegan DF, Kongsom S, Vuthikornudomkit S and 5 others (1992) Occurrence, diagnosis and treatment of shrimp diseases in Thailand. In: Fulks W, Main KL (eds) Diseases of cultured penaeid shrimp in Asia and the United States. Oceanic Institute, Honolulu, HI, p 57-112

Flegel TW, Nielsen L, Thamavit V, Kongtim S, Pasharawipas $T$ (2004) Presence of multiple viruses in non-diseased, cultivated shrimp at harvest. Aquaculture 240:55-68

Hengartner MO (2000) The biochemistry of apoptosis. Nature 407:770-776

Kalagayan G, Godin D, Kanna R, Hagino G, Sweeney J, Wyban J, Brock J (1991) IHHN virus as an etiological factor in runt-deformity syndrome of juvenile Penaeus vannamei cultured in Hawaii. J World Aquacult Soc 22: $235-243$ 
Kerr JFR, Winterford CM, Harmon BV (1994) Morphological criteria for identifying apoptosis. In: Celis JE (ed) Cell biology: a laboratory handbook. Academic Press, San Diego, CA, p 319-329

Lightner DV (1996a) Epizootiology, distribution and the impact on international trade of two penaeid shrimp viruses in the Americas. Rev Sci Technol 15:579-601

Lightner DV (1996b) A handbook of pathology and diagnostic procedures for diseases of penaeid shrimp. World Aquaculture Society, Baton Rouge, LA

Lightner DV, Redman RM, Bell TA (1983a) Detection of IHHN virus in Penaeus stylirostris and $P$. vannamei imported into Hawaii. J World Maricult Soc 14:212-225

Lightner DV, Redman RM, Bell TA (1983b) Infectious hypodermal and hematopoietic necrosis, a newly recognized virus disease of penaeid shrimp. J Invertebr Pathol 42: $62-70$

Mari J, Bonami JR, Lightner D (1993) Partial cloning of the genome of infectious hypodermal and haematopoietic necrosis virus, an unusual parvovirus pathogenic for penaeid shrimps; diagnosis of the disease using a specific

Editorial responsibility: Timothy Flegel,

Bangkok, Thailand probe. J Gen Virol 74:2637-2643

Primavera JH, Quinitio ET (2000) Runt-deformity syndrome in cultured giant tiger prawn, Penaeus monodon. J Crustac Biol 20:796-802

Reed JC (2000) Mechanism of apoptosis. Am J Pathol 157: 1415-1430

Regenmortel MHVV, Fauguet CM, Bishop DHL, Carsteus EB and 7 others (2000) Virus taxonomy for the 7 th ICTV report: Brevidensovirus. Academic Press, San Diego, CA

Shike H, Dhar AK, Burns JC, Shimizu C, Jousset FX, Klimpel KR, Bergoin M (2000) Infectious hypodermal and hematopoietic necrosis virus of shrimp is related to mosquito brevidensoviruses. Virology 277:167-177

Tang KF, Lightner DV (2001) Detection and quantification of infectious hypodermal and hematopoietic necrosis virus in penaeid shrimp by real-time PCR. Dis Aquat Org 44:79-85

Tang KFJ, Poulos BT, Wang J, Redman RM, Shih HH, Lightner DV (2003) Geographic variations among infectious hypodermal and hematopoietic necrosis virus (IHHNV) isolates and characteristics of their infection. Dis Aquat Org 53:91-99

Submitted: October 4, 2004; Accepted: March 8, 2005

Proofs received from author(s): November 17, 2005 